\title{
The Word "Islamophobia" As a Terminus Technicus of Social Sciences?
}

\author{
Miloš Mrázek
}

https://doi.org/10.14712/25704893.2017.8

\begin{abstract}
The topic of this article is the appropriateness of usage of the popular term "islamophobia" in the vocabulary of social sciences. It deals with the difference between particular academical discourses (philosophy, theology, religious studies) and especially between the academical discourse in general and ideological language. After a summary of the history of the term, its current usage is analyzed, which leads to the conclusion that social scientists should not look for a precise definition, since the term itself and its usage is part of the reality (political activism, ideology), which should be a subject of unbiased study.
\end{abstract}

Keywords: islamophobia, xenophobia, ideology, academic discourse, methodology of social scences, terminology

\begin{abstract}
Abstrakt: Př́spěvek se zaobírá otázkou, nakolik má dnes hojně užívaný termín „islamofobie“ místo v religionistice, sociologii či obecně v sociálních vědách. Nejprve se věnuje otázce specifičnosti sociálně-vědního diskurzu ve srovnání s jinými, přičemž zvláštní pozornost je věnována ideologickému jazyku. Článek se stručně věnuje dějinám užívání slova „islamofobie“, termín je dán do kontextu jiných slov s príponou „-fobie“, včetně těch, které mají místo $\mathrm{v}$ odborném medicínském slovníku. V závěru autor konstatuje, že termín, tak jak se běžně používá, je natolik nepřesný a ideologicky zatížený, že jeho uživání v odborném jazyce není vhodné. Spíše než jako nástroj porozumění realitě je sám součástí reality, jež má být vědecky zkoumána.
\end{abstract}

Klíčová slova: islamofobie, xenofobie, odborná terminologie, ideologie, vědecký diskurz, metologie sociálnách věd

Received: 19 October 2016, Accepted: 2 March 2017

Published online: 13 November 2017

Mgr. et Mgr. Miloš Mrázek, Th.D.

University of Pardubice

e-mail:mimrazek@email.cz

(C) 2017 The Author. This is an open-access article distributed under the terms of the Creative Commons Attribution License (http://creativecommons.org/licenses/by/4.0), which permits unrestricted use, distribution, and reproduction in any medium, provided the original author and source are credited. 
We are used to, when talking about Islam in general and about Muslim minorities in Western countries in particular, hearing or reading the term "islamophobia". The politicians, journalists, political activists, and often social scientists (in the broad sense of the word, including the Islamic and religious studies) take it for granted. Now we want to deal with this term with critical distance in the following text. ${ }^{2}$

The question is: Is it appropriate to call various negative attitudes and behaviors towards Islam and its followers "islamophobia"?

In fact, there are two questions here:

1) Is there any place for this word in the common language?

2) Is there any place for this term in the discourse of social sciences?

Our aim is to deal with the second one: Is there any definition of "islamophobia" in the social science language?

We are not going to express our own opinions about the position of Muslims in Europe, about immigration from Muslim countries, about Islam in general, or about anti-Muslim movements or anti-immigrant movements. We will stay on the level of methodology or theoretical terminology of social sciences.

\section{"Islamophobia" in academic discourse}

The key question, therefore, is, where this term belongs, where it was originally defined. It means what discourse it belongs to.

The difference between discourses lies not in different subjects, but also different starting points. Here are examples of words, the definitions of which is meaningful only in specific discourses: Terms like "nature", "knowledge", "evil" are "at home" primarily in philosophy; "grace", "revelation" or "sin" belong to a religious or theological vocabulary, and we can find the definitions of terms like "statistical normality", "socialization" or "social deviation" in works of social scientists. If a sociologist or even a philosopher said what sin was or wasn't, they would be crossing the boundaries of their competences, given and limited by the methodology either of philosophy of empirical science, for these concepts are not defined there.

Obviously, in many cases there are no clear boundaries between specific discourses, which may cause problems when dealing with a concept defined in one area in a different area. Sometimes one term gets taken over or borrowed and redefined, which means it denotes a new concept. Let us take for example, the term "church", which was originally used in the sociology of religion in a sense defined by early sociologists like Max Weber and which had nothing to do with the concept of Christian theology.

1 In October 2016, there were 5570000 results for "islamophobia" on Google.

2 Some years ago, there was a discussion about the legitimacy of this term in the journal for contemporary religions Dingir. The following text is an extension of one contribution to this discussion. Now the topic is even more pressing, due to recent events in Europe and their reflections in both the public and academic space. 
Sometimes the redefinition is not so clear, which causes problems - that is the case of the second term in Weber's "church-sect" ideal typology. ${ }^{3}$

Besides the above-mentioned discourses (philosophy, theology and social science), there is another one to be mentioned, for it often meets the former discourses on the same subject (people and their behavior). It is also an area with its own ways of using language and argumentation and mainly its own aims. Here are examples of terms or concepts typical for last mass ideologies of the last century: "pure race", "new man", "classless society" or "reactionary". We have experienced a tragic fusion of ideologies with sciences ("race theory", "scientific worldview"). Ideologization of scientific or academic discourse in general is again a topical issue these days. "The ideologues who have been in the ascendancy for the last thirty years have deformed science into an instrument of agitation and propaganda [...] The core scientific principle of objectivity has been ignored in practice and denied validity in theory. Thus a large number of sociologists have become active combatants in the 'culture wars', almost always on one side of the battle lines. [...] In recent years this version of sociology has intoned the mantra of 'class, race, and gender', "wrote the doyen of sociology of religion P. L. Berger, some years ago. ${ }^{4}$

The boundary between scientific (academic) and ideological language is to be of concern to us here if we are to deal with the term "islamophobia".

There are plenty of definitions of what ideology is. ${ }^{5}$ For our arguments, we can use the following, quite broad one, which says that " $[a] n$ ideology is a more or less coherent set of ideas that provides the basis for organized political action, whether this is intended to preserve, modify or overthrow the existing system of power."

The difference between the language of sciences and ideologies is that the goal of the former is an expression of knowledge, whereas that of the latter one is a motivation to social or political action and the language itself is one of the means of such behavior. Like religious terms, for social sciences, ideological terms are part of the subject of inquiry; a part of reality, not a means to be used for studying reality, since they do not structure their definitions.

Let us recall the words of E. Voegelin, who complained about conceptual confusions that arise when the area of reality is mixed with the area of science (theory), or - as he says - symbols of reality and the theories explaining these symbols. In the context of the study of ideologies like Fascism or Socialism, he stated, that "movements of the suggested type, together with their symbolisms, ${ }^{7}$ were part of reality, [and]

3 See Miloš Mrázen, “Terminologické problémy studia alternativní religiosity”, Theologická revue $(1,2005):$ p. 55-63.

4 Peter L. Berger, “Whatever Happened to Sociology?”, First Things 34 (2002): p. 117.

5 For some of definitions see PaVel Šaradín, Historické proměny pojmu ideologie [Historical Changes of the term "Ideology"], Brno: CDK, 2001; or AndRew Heywood, Political Ideologies: An Introduction, $6^{\text {th }}$ ed., London: Palgrave 2017, p. 9-10.

6 Martin Selinger, Politics and Ideology, London: Allen \& Unwin, 1976; quoted acc. to Heywood, Political Ideologies, p. 10.

7 This means terms from the vocabulary of the particular ideology: "If the theorist, for instance, describes the Marxian idea of the realm of freedom, to be established by a Communist revolution, as an immanentist hypostasis of a Christian eschatological symbol, the symbol 'realm of freedom' is part of reality; it is part of a secular movement of which the Marxist movement is a subdivision, while 
that only concepts could be defined but not reality, and that it was highly doubtful whether the language symbols in question could be critically clarified to such a point that they were of any cognitive use in science."

\section{The origin of the concept of Islamophobia}

Let us return to the term "islamophobia". The question is whether the term is scientifically definable or whether it is a "language symbol" belonging to the vocabulary of an ideology, which is the subject of scientific inquiry.

First we have to make a short historical overview of this word. Sources are not in agreement concerning its first usage. We can find statements in the Runnymede Trust as late as $1997^{9}$, with a reference to the Oxford English Dictionary, saying that the neologism was coined in late eighties and in the printed form as late as in $1991 .{ }^{10}$ In the present, the article "L'état actuel de l'islam dans l'Afrique occidentale française" (1910) by the French Africanist Maurice Delafosse and the following book La politique musulmane dans l'Afrique Occidentale Française written by Alain Quellien, a French colonial bureaucrat, and published in Paris in the same year are usually mentioned as the first printed texts containing the term "islamophobia". Both authors used the word in the context of affairs in French colonies. Quellien, criticizing the colonial authorities for their ignorance of the real situation in the Muslim colonies, used the term islamophobes for those who considered the Muslims to be "the natural and irreconcilable enemy of the Christian and the European". ${ }^{11}$ Afterwards, we find this neologism (without any explicit definition) in the work of the French painter and convert to Islam Alphonse Étienne Dinet and his Algerian friend Slimane Ben Ibrahim. In 1918, they published Muhammad's biography ${ }^{12}$ dedicated to Muslims fallen in their service in the French army, and four years later the essay L'Orient vu de l'Occident. The context of the usage is criticism of the Orientalist and Jesuit Henri Lammens, whose works are an example of "the degree of aberration to which Islamophobia can lead a learned man". Here is "islamophobia” a concept of the author's prejudice, which mean the goal of his work is not science, but rather a "pseudo-scientific crusade in the hope of bringing Islam down once and for all'. ${ }^{13}$ In the review L'Orient vu de l'Occident,

such terms as 'immanentist,' 'hypostasis,' and 'eschatology' are concepts of political science." ERIC Voegelin, The New Science of Politics, The University of Chicago Press, 1952, p. 29.

${ }^{8}$ Voegelin, The New Science of Politics, p. 30.

${ }^{9}$ See bellow.

${ }^{10}$ In journal Insight in the context of the hostile relationship of the Soviet regime to Afghan Muslim.

11 Acc. to Fernando Bravo López, "Towards a Definition of Islamophobia: Approximations of the Early Twentieth Century”, Ethnic \& Racial Studies (4, 201), p. 567. Comp. RoBIN Richardson, "Islamophobia or Anti-Muslim Racism - or What? - Concepts and Terms Revisited" (online), Insted, 2012, retrieved September 2016, p. 3, available online at http://www.insted.co.uk/anti -muslim-racism.pdf.

${ }^{12}$ La vie de Mohammed, prophète d'Allah, Paris: H. Piazza 1918, 305 p.

13 Etienne Dinet and Sliman Ben Ibrahim, L'Orient vu de l'Occident, H. Piazza 1925, p. 26 a 20. According to BRAvo, “Towards a definition...”, p. 564. 
in the October issue of the Oxford Journal for Theological Studies in 1923, we find most likely the first usage of the word "islamophobia" in printed English. ${ }^{14}$ However, the English translation of La vie de Mohammed translates "l'islamophobie" as "feelings inimical to Islam".

But these and a few occasional authors afterwards, ${ }^{15}$ "were not employing the term in such ways that it reflects the contemporary concept or usage." ${ }^{16}$ This changed as late as in 1980s. What is interesting is that the authorship of the neologism, which has been used in the public discourse since then, is claimed by (or is ascribed to) several different Muslim activists advocating the interests of their minorities in the $\mathrm{UK}^{17}$ and the USA ${ }^{18}$. We should also note, that the term was used by mullahs during the time of the Iranian Revolution to label opponents of islamization, e. g. women denying to wear a hidjab. ${ }^{19}$

There is quite a broad consensus that the current way of dealing with this term is influenced in a large extent by publications of the left-wing think-tank Runnymede Trust. ${ }^{20}$ First it was the report $A$ Very Light Sleeper in 1994, where "anti-Muslim feeling [...] also sometimes known as Islamophobia" are mentioned in the context of anti-Semitism. ${ }^{21}$ Three years later another report was published, this time just about this issue: Islamophobia - A Challenge for Us All. Its authors define the term as " a useful shorthand way of referring to dread or hatred of Islam - and, therefore, to fear or dislike of all or most Muslims"22 and "unfounded hostility towards Islam" 23 characterized by a so called closed view of Islam as:

1) a monolithic and static bloc,

2) separated from other cultures, not having aims or values in common with them

3) barbaric, irrational, primitive and sexist, and therefore inferior to the West

4) violent and aggressive, engaged in "a clash of civilizations"

5) rather a political ideology than a genuine religion.

This view is further characterized by

6) unwillingness to discuss the Muslim criticism of the West

7) justifying discriminatory practices of Muslims in society, and as the last

8) acceptance of anti-Muslim hostility as something natural and "normal". ${ }^{24}$

14 "Certain writers in particular are blamed for their 'Islamophobia'." StAnley A. Cook, "The History of Religions", Journal for Theological Studies (25, 1923): p. 101.

${ }^{15}$ Viz Bravo, "Towards a definition...", p. 574n.

${ }^{16}$ Christopher Allen, Islamophobia, Farnham: Ashagate 2010, p. 5.

${ }^{17}$ Allen, Islamophobia, p. 6.

${ }^{18}$ See "Moderate Muslims Speak Out on Capitol Hill" (online), IPT News, October 2010, retrieved September 2016, available online at http://www.investigativeproject.org/2217/moderate-muslim -speak-out-on-capitol-hill.

${ }^{19}$ Allen, Islamophobia, p. 6.

20 "With the publication of the Runnymede report in 1997, not only did the report significantly influence the way in which Islamophobia was understood but so too did it ensure that Islamophobia was afforded public and political recognition." ALLEN, Islamophobia, p. 15n.

${ }^{21}$ A Very Light Sleeper: The Persistence and Dangers of Antisemitism, London: Runnymede Trust 1994 (reprinted November 1997), p. 55.

${ }^{22}$ Islamophobia - A Challenge for Us All, London: Runnymede Trust 1997, p. 1.

${ }^{23}$ Islamophobia..., p. 4.

${ }^{24}$ Islamophobia..., p. 5. 
As we already mentioned, this publication has fundamentally contributed to spreading the use of the term with such a definition in the language of politicians, activists, journalists, and authors of textbooks, and it is often present in many proclamations. Not surprisingly, with this spreading of the concept, its criticism has appeared too - from the part of those, who are described by this label, but also from scholars discussing both the adequacy of the aforementioned definition and the legitimacy of the term itself. The reason for the refutation of the concept is very often presented as advocacy of freedom of speech and legitimate warnings of the totalitarian tendencies of the proponents of political correctness. G. Orwell's concepts of Newspeak or Thoughtcrime are often mentioned in this context. ${ }^{25}$ The words of Abdur-Rahman Muhammad, the former imam and member of International Institute for Islamic Thought, now a critic of islamization from the position of "moderate Islam", are sometimes quoted too: "This loathsome term, is nothing more than a thought-terminating cliche conceived in the bowels of Muslim think tanks for the purpose of beating down critics." 26

\section{"Islamophobia" as a terminus technicus?}

We therefore see, that both the usage of the term "islamophobia" and its criticism are weapons on the battlefield of political activism. It is used not as a cognitive means, but rather as "the basis for organized political action". The term then becomes a part of reality to be scientifically described, analyzed and explained. The task of science is not to look for a precise definition, like Christopher Allen, in his concise critical analysis of the Runnymede report ${ }^{27}$, or Erich Bleich ${ }^{28}$ tried to provide. Its task is to classify the term in question, to understand its development in different socio-cultural conditions etc., which requires an adequate distance.

An example of unfortunate results of an uncritical reception of the concept into the sociological vocabulary is mentioned by the German scholar Johannes Kandel from Friedrich-Ebert-Stiftung. After his rejection of the Runnymede report's characteristics of islamophobia as too vague and excluding any critical discussion about Islam, he mentioned a research led by a well-known sociologist, Wilhelm Heitmeyer.

${ }^{25}$ Matthew Vadum, "Lifting the Veil on the 'Islamophobia' Hoax" (online), Foundation Watch, December 2015, p. 1-11, available online at http://capitalresearch.org/wp-content/uploads /FW1215.pdf; Robert Spencer, “The Basics of Islam, Part 1 - 'Islamopohobia” (online), Jihad Watch, April 2016, accessed September 2016, available online at https://www.jihadwatch .org/2016/04/video-robert-spencer-explains-the-islamophobia-scam.

${ }^{26}$ A quote from the stormy debate over the issue of whether there should be a mosque on the spot of the WTC Tweens in New York. See e. g.: Claire Berlinski, "Moderate Muslim Watch: How the Term 'Islamophobia' Got Shoved Down Your Throat, (online)” Ricochet, November 2010, retrieved September 2016, available online at https://ricochet.com/archives/moderate-muslim -watch-how-the-term-islamophobia-got-shoved-down-your-throat/.

27 Allen, Islamophobia, p. 190.

${ }^{28}$ ERIK BleICH, "What Is Islamophobia and How Much Is There? Theorizing and Measuring an Emerging Comparative Concept”, American Behavioral Scientist (12, 2011): p. 1585. 
He "measured" the islamophobia in German society since 2002. The claim that this phenomenon has grown was based on the ratio of affirmative and negative answers to theses such as:

9) "Muslims in Germany should have the right to live according to their own laws."

10) "It is up to Muslims alone to decide when they call the faithful to prayer by loudspeaker."

Kandel stated that according to this research, the rise of islamophobia is "scientifically proven" on the basis, that a part of society rejects physical punishments for adultery or apostasy, or does not wish to be disturbed by the muezzins' voice. ${ }^{29}$ Regarding the fact, that the aim of such research is not knowledge but interference in society, fighting islamophobia in this case, we can consider it an example of ideologization, similar to what P. Berger warned about.

\section{Islamophobia as an illness?}

The term "islamophobia" clearly refers to a group of other terms, which signify certain mental disorders, such as claustrophobia, agoraphobia, androphobia, arachnophobia or social phobia. Needless to say, these are technical terms defined by competent scientists - psychopathologists. They describe symptoms allowing an appropriate differential diagnosis (e. g. tachycardia, trembling, difficulty breathing or dizziness). ${ }^{30}$

What is interesting, so called ekklesiophobia can be found among them. Analogically, to the concept of islamophobia as is it used today, we could think, that it would be "unfounded hostility towards Christian churches". Nevertheless, it is really a medical diagnosis; a case when a person shows symptoms of panic fear of churches or other sacral buildings. "Islamophobia" should then be a terminus technicus for a disorder when a person shows symptoms like tachycardia, trembling, difficulty breathing or dizziness when hearing a muezzin or touching Quran.

Of course, such mental disorder may occur and it would be similar to the clinical xenophobia. In fact, "islamophobia" is usually used as a specific kind of xenophobia. But this term itself is even more confusing as a terminus technicus in social sciences: As a diagnosis, it has its place among specific (isolate) phobias. Psychiatrists started to use this term for cases, when a person shows typical phobic reactions, due to some traumatic experience (as was the case of Americans veterans of wars in Korea and Vietnam), when coming into contact with anybody is similar to the person who

${ }^{29}$ Johannes Kandel, "Islamophobia - On the Career of a Controversial Term, (online)" Friedrich-Ebert-Stiftung 2006, retrieved September 2016, p. 5-6, available online at http://www.fes.de /BerlinerAkademiegespraeche/publikationen/islamundpolitik/documents/Islamophobia.pdf.

${ }^{30}$ See e. g.: Ján PrašKo, Jana PrašKová and Hana PrašKová, Specifické fobie [Specific Phobias], Praha: Portál 2008, p. 39. 
caused the trauma (e. g. people with Asiatic features). ${ }^{31}$ Such persons require treatment, just like other patients with any kind of phobia. A good illustration may be the Supreme Court of the USA decision in Colorcraft Corp., Fuqua Industries, Inc. v. Jandrucko in 1991, ratifying a case when an administrative law judge awarded a woman in Florida compensation, when her employer did not comply to her demand, that she be allowed not to come in contact with any African-American males in her work. Her clinical phobia toward black people developed after being attacked by a black man when doing her field job. She was able to prove, that it was not racism, but that her "negrophobia" was part of her post-traumatic stress disorder (PTSD), that she was trying to overcome through psychotherapy. ${ }^{32}$

This instance is an illustration of the need for distinguishing between socio-pathologiacal hatred towards minorities and psycho-pathological diagnoses. Every term with the suffix "-phobia", including "islamophobia", should be a part of scientific or academic vocabulary, reserved just for the second case. After all, PTSD may include a form of pathological fear of Muslims, e. g. after surviving an Islamist terrorist attack.

Advocates of the term "islamophobia" as a name for hostility toward Islam or Muslims use the argumentation that its similarity with the terms referring to clinical phobias is just phonetic. Of course, an etymological definition may be sometimes misleading - e. g. hemophilia is not a pathological affection to blood. But even just the ambiguous usage of "xenophobia" blurs the boundary between the psycho-pathological and "sociological" understanding. ${ }^{33}$ Moreover, this is also the case of another "phobia", which is very often associated with islamophobia - homophobia. George Weinberg, who coined this term in the late sixties in the context of his struggle to delete homosexuality from the lists of diagnoses, ${ }^{34}$ still struggles against classifying it as an illness, as opposed to the discrimination of homosexuals (not just a panic fear of one's own homosexuality). In the context of the official deletion of terms with the suffix “-phobia”, except for their proper medical meaning, from the vocabulary of the American Associated Press reporters, he wrote, that " $t]$ he word conveyed that gay people were not the ones suffering from an emotional problem; their oppressors were". ${ }^{35}$

31 “Xenophobia”, (online), All About Counseling, retrieved October 2016, available online at https:// www.allaboutcounseling.com/library/xenophobia/.

32 See John M. CASey, "From Agoraphobia to Xenophobia: Phobias and Other Anxiety Disorders Under the Americans with Disabilities Act” (online), University of Pudget Sound Law Review 17, Seattle: Seatle University of Law 1994, p. 408, 413, available online at http://digitalcommons.law .seattleu.edu/cgi/viewcontent.cgi? article $=1422 \&$ context $=$ sulr.

33 See e. g.: Peter F. Omoluabi, "Psychological Foundation of Xenophobia”, in A. A. Olowu (ed.), Xenophobia: A Contemporary Issue in Psychology, Ile-Ife: The Ife Centre for Psychological Studies 2008, p. 53-71, where author promiscuously use both psycho-pathological and social meaning of the term.

${ }^{34}$ Gabrielle Kuby, Globální sexuální revoluce [Global Sexual Revolution], Brno: Jiří Brauner - Kartuziánské nakladatelství 2014, p. 164n.

35 George Weinberg, "Homophobia: Don't Ban the Word - Put It in the Index of Mental Disorders", (online) The Huffington Post, 12. 6. 2012, retrieved October 2016, available online at http://www .huffingtonpost.com/george-weinberg/homophobia-dont-ban-the-w_b_2253328.html. 
The problem of using such a term in academic vocabulary lies also in the fact that, due to its inherent reference to a sick mind (but not in the strict medical meaning), it has achieved a certain emotional nature. The term may grant the power to ostracize and "excommunicate" people from the society of "normal" and correct-thinking and -behaving persons (regardless of whether their criticism is irrational or not). On the other hand, it may also exonerate, diminsh the responsibility for one's expression of hatred.

Here lies the fundamental difference between the concept of islamophobia and the concept of anti-Semitism, which often get associated. ${ }^{36}$ The latter does not have such an emotional charge. The counterpart to "islamophobia" is not "anti-Semitism", but "judeophobia", which is also sometimes used today. ${ }^{37}$ Nevertheless, this word is even older that the first known usage of "islamophobia" - already at the end of the $19^{\text {th }}$ cent., the physician and Zionist activist tried to introduce it Leon Pinsker, who considered hostility toward Jews to be a specific illness. Shlomo Avineri comments that "because he was a doctor, such quasi-clinical explanations obviously appealed to Pinksner's mind, but the terminology, of course, begging the question. By saying that judeophobia is the cause of Jew-hatred, Pinsker really says that non-Jews fear Jews because they are affected by a malady whose main symptom is a fear ofJews. Such an explanation is simplistic and lacks an adequate historical dimension." 38 There is also no reason to apply such argumentation to "islamophobia".

\section{Conclusion}

The question of this text was "is there a place for the term 'islamophobia'?" in the vocabulary of social sciences (incl. islamologists and religious studies scholars) as their terminus technicus. Is there any possible definition respecting boundaries of this academic field? In our brief summary of the history of the term, an important fact has been noted: that originally it was used by activists (Muslims, multiculturalists), and not by scholars. Most importantly, we have noticed an overly broad and vague definition, which was introduced into public discourse by the think-tank Runnymede Trust. This definition covers not just socio-pathological manifestations of hatred, but also some legitimate critical studies of Islam. A comparison of "islamophobia" to definitions of clinical phobias revealed certain intrinsic negative emotions.

Social scientists should not look for a precise definition, as it is not their job to define ideological terms (such as "pure race" or "reactionary"). The usage (or rejection) of such terms, or rather symbols, in political debates is to be tied to reality, which should be the subject of critical academic study. This means a resignation to the objectivity of non-partisan inquiry.

${ }^{36}$ See e. g. the Runnymede Trust report $A$ Very Light Sleeper.

${ }^{37}$ See e. g. Pierre-André TAguieff, La Judéophobie des Modernes, Paris: Odile Jacob 2008, 686 p.

${ }^{38}$ Shlomo Avineri, The making of modern Zionism: The intellectual origins of the Jewish State, New York 1981, p. 77. 


\section{REFERENCES}

Allen, Christopher, Islamophobia, Farnham: Ashagate Publishing Company 2010, $210 \mathrm{p}$.

AvineRI, Shlomo, The making of modern Zionism: The intellectual origins of the Jewish State, New York: Basic Books, 1981, 254 p.

Berger, Peter L., "Whatever Happened to Sociology?”, First Things 34 (2002): p. 115-118.

Berlinski, Claire, "Moderate Muslim Watch: How the Term 'Islamophobia' Got Shoved Down Your Throat," (online), Ricochet (November 2010), retrieved 2016, available online at https://ricochet.com/archives/moderate-muslim-watch-how-the-term -islamophobia-got-shoved-down-your-throat/.

BleICH, ERIK, "What Is Islamophobia and How Much Is There? Theorizing and Measuring an Emerging Comparative Concept", American Behavioral Scientist (12, 2011): p. 1581-1600.

Bravo Lopez, Fernando, "Towards a Definition of Islamophobia: Approximations of the Early Twentieth Century”, Ethnic \& Racial Studies (4, 2011): p. 556-573.

Casey, John M., From Agoraphobia to Xenophobia: Phobias and Other Anxiety Disorders Under the Americans with Disabilities Act, 17 Seatle University of Law (online), 1994, retrieved 2017, available online at http://digitalcommons.law.seattleu.edu/cgi /viewcontent.cgi article $=1422 \&$ context $=$ sulr.

Heywood, Andrew, Political Ideologies: An Introduction, ${ }^{\text {th }}$ ed., London: Palgrave 2017. Islamophobia - A Challenge for Us All, London: Runnymede Trust 1997, 70 p.

KAndel, Johannes, "Islamophobia - On the Career of a Controversial Term", (online), Friedrich-Ebert-Stiftung, 2006, retrieved 2016, p. 5-6, available online at http://www .fes.de/BerlinerAkademiegespraeche/publikationen/islamundpolitik/documents /Islamophobia.pdf.

Omoluabi, Peter F., "Psychological Foundation of Xenophobia", in A. A. Olowu (ed.), Xenophobia: A Contemporary Issue in Psychology, Ile-Ife: The Ife Centre for Psychological Studies, 2008.

Praško, Ján, Hana PrašKová and Jana PrašKová, Specifické fobie [Specific Phobias], Praha: Portál 2008, 219 p.

RICHARDSON, Robin, "Islamophobia or anti-Muslim racism - or what? - concepts and terms revisited", (online), Instead, 2012, retrieved September 2016, available online at http://www.insted.co.uk/anti-muslim-racism.pdf.

Spencer, Robert, “The Basics of Islam, Part 1 - 'Islamopohobia'” (online), Jihad Watch, April 2016, accessed September 2016, available online at https://www.jihadwatch .org/2016/04/video-robert-spencer-explains-the-islamophobia-scam.

Vadum, Matthew, "Lifting the Veil on the 'Islamophobia' Hoax" (online), Foundation Watch, December 2015, Accessed September 2016, available online at http:// capitalresearch.org/wp-content/uploads/FW1215.pdf.

A Very Light Sleeper: The Persistence and Dangers of Antisemitism, London: Runnymede Trust 1994 (Reprinted November 1997), 64 p.

Voegelin, ERIC, The New Science of Politics, The University of Chicago Press, 1952, 193 p. 